\title{
Karst Relief Development History of Zemo Imereti Plateau, Georgia, Caucasus
}

\section{Zaza Lezhava1, Kukuri Tsikarishvili, Lasha Asanidze1, Nino Chikhradze², Giorgi Chartolani1, Ani Sherozia1}

${ }^{1}$ Vakhushti Bagrationi Institute of Geography, TSU, Tbilisi, Georgia

${ }^{2}$ School of Natural Sciences and Engineering, Ilia State University, Tbilisi, Georgia

Email: lasha.asanidze@tsu.ge

How to cite this paper: Lezhava, Z., Tsikarishvili, K., Asanidze, L., Chikhradze, N., Chartolani, G. and Sherozia, A. (2019) Karst Relief Development History of Zemo Imereti Plateau. Georgia, Caucasus. Open Journal of Geology, 9, 201-212.

https://doi.org/10.4236/ojg.2019.93014

Received: February 21, 2019

Accepted: March 23, 2019

Published: March 26, 2019

Copyright $\odot 2019$ by author(s) and Scientific Research Publishing Inc. This work is licensed under the Creative Commons Attribution International License (CC BY 4.0).

http://creativecommons.org/licenses/by/4.0/

\section{Open Access}

\begin{abstract}
The history of karst terrestrial development has been restored on the background of many years' field, experimental and laboratory researches (underground water tracing, structural deciphering of aerophotocytes, analysis of boreholes and geological wounds) and analysis of the current literary sources carried out by us in the Zemo Imereti Plateau. Within the study area, karst and karst forms of the Jurassic-Cretaceous, Lower Tertiary (Paleocene-Eocene) and Post-Miocene (Sarmati) period were revealed. Lithobiostratigraphic analysis of cave subterranean sediments enabled us to identify the cave age. In Zemo Imereti Plateau, in the caves located on higher hypsometric levels, the sedimentation of subterranean sediments began in the Middle-Upper Pleistocene and it seemed that the caves' formation was mainly completed in the mentioned territory.
\end{abstract}

\section{Keywords}

Karst, Cave, Plateau, Zemo Imereti, Georgia

\section{Introduction}

The Zemo Imereti Plateau geotectonically comprises the central-Dzirula uplifting zone of the Georgian block (Dzirula crystalline massif) [1] [2]. Dzirula massif, which coincides with the Zemo Imereti Plateau, represents a comparatively uplifted part of the intermountain strip of the Greater Caucasus and Lesser Caucasus. The karst region of the Zemo Imereti Plateau includes the eastern most part of the western Georgia karst strip and represents the only platform karst region in Georgia [3] [4]. The evolution of the Zemo Imereti Plateau relief took place on the background of the development of the relief of the southern 
slope of the Greater Caucasus and was related to the adjoining massifs.

The Zemo Imereti Plateau has passed the long and hard way (frequent alternation of continental and sea regimes) of geological development, which is well reflected in modern relief. It is very important to note that the relief has been developed in the geosyncline of the southern slope of the Racha Range and in the platform conditions of Dzirula massif (Zemo Imereti Plateau). In this massif two genetically different groups of relief are distinguished. The buried peneplain (the crystalline massiff's denudated surface is located into several hundreds of meters deep) is represented in the Upper Cretaceous and Oligocene-Miocene deposits distribution strip [5]. The above mentioned structural plateau underwent significant uplifting during the end of the Tertiary and Quaternary, though it was behind the dug-up peneplain distribution areas by uplifting amplitude and both were behind the southern slope of the Racha Range (Figure 1).

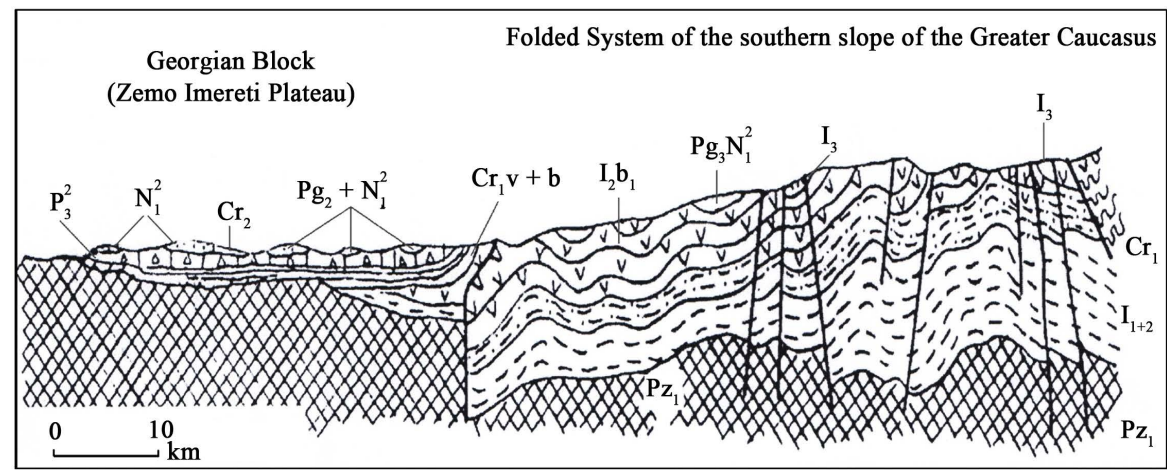

Figure 1. Geological cross-section of the folded system of the southern slope of the greater caucasus and block of Georgia.

The development of karst relief of the study area is closely related to its geological development. In this regard, in the work, the origin and development of karst relief has been discussed in the context of the detailed geological development of the region.

When we analyzed the geological history of the region, we used the works of Bogachov [6], Markov [7], Gamkrelidze [8], Kuznetsov [9], Janelidze [10] [11], Kakhadze [12] [13], Chikhelidze [14], Shiriashvili [15], Geguchadze [16], Kuchukhidze [17] and others. Also, the results of field, experimental and laboratory researches were carried out by us over years.

The history of the development of the Pre-Jurassic period is not sufficiently studied not only for the research territory, but also for whole Georgia. But the fact was that a large part of the Zemo Imereti Plateau was a land before Mid-Lias and underwent washing [13] [14], while the southern slope of the neighboring Racha Range underwent sinking. Before Lias or in Lower Lias the volcanism had revived, resulting in sedimentation of tuffits with sandstones and clay lenses that indicated the continental nature of this suite (Figure 2). 

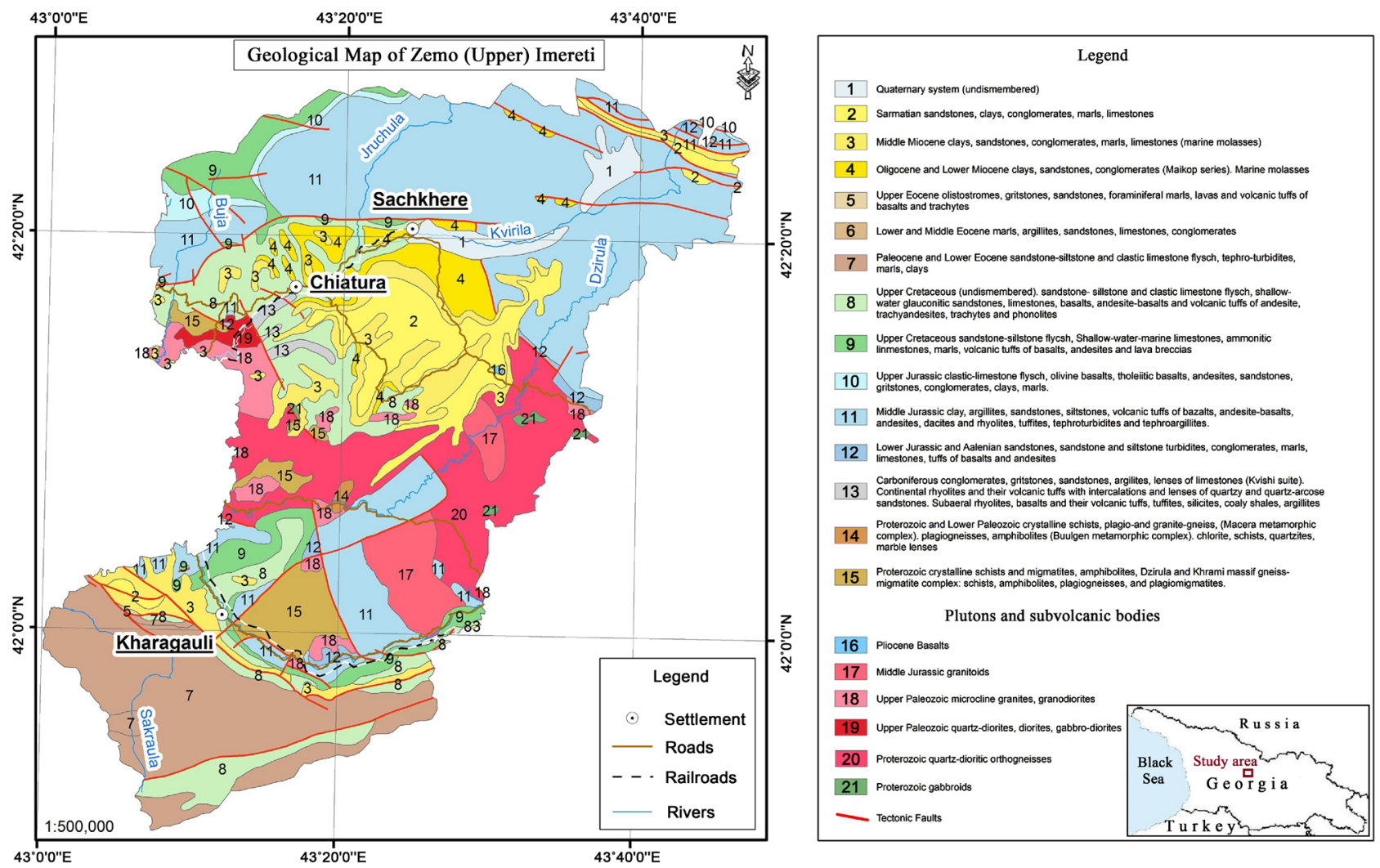

Figure 2. Geological map of the Zemo Imereti Plateau (After Gudjabidze, 2003) [18].

\section{Research Methods}

In the frames of the presented research, various research methods were used and conducted several years of field researches, experimental and laboratory studies, including the underground water tracing, structural decoding of satellite images, analysis of data from the boreholes and geological sections and existing literary sources, lithobiostratigraphic study of cave subterranean deposits and etc.Based on the above mentioned, the history of the development of Zemo Imereti karst relief was restored.

On the basis of analysis of boreholes and geological sections, topography of upper tectonic level of Zemo Imereti Plateau (Meso-Cenozoic) has been restored. Also, directions and layout conditions of the underground karst waters movement have been identified by indicator experiments. On the basis of the analysis of cave's terrigenous sediments (petrographic, chemical and x-ray structural), the paleogeographical picture of the region and caves has been restored. On the basis of the above mentioned, the history of the development of karst relief of Zemo Imereti has been restored. The upper age of the formation of the caves has been identified.

\section{Results and Discussion}

As mentioned above, before Middle Lias a large part of Zemo Imereti Plateau was a land and was under the water erosion. 
In the Middle of Lias begins sea transgression and continues to Aalenian. The invading sea does not cover the entire area and the terrestrial local areas remain, from where the washing continues.At this time the coastal strip sediments are deposited on the denudation-abrasive surface of the Dzirula crystalline massif. Gradually in Middle Lias the sea expansion and deepening takes place, resulting in the deposition of color limestones of several tens of meters thick that are well represented in the areas of Katskhi, Salieti, Shrosha and others.

At the end of Upper Lias, the tectonic movements in the Aalenian cause the uplift of the significant part of the massif and turn into terrain, and its washing in the following century. It is supposed that at this time the karstification of the Middle Lias red limestones should have been started.

In Bajocian, a significant part of the massifagain undergoes the sea transgression and sinking. At this time an underwater volcanism takes place on the southern slope strip of the Racha Range and the Dzirula massif, resulting in a deposition of powerful porphyritic suite $(1.5$ - $3 \mathrm{~km}$ thick in the Racha Range strip, and about $1 \mathrm{~km}$ thick in the Dzirula massif). A small part of the massif still remains as a land and its washing continues.

In Bathonian there is a powerful mountain formings phase, which led to the suspension of volcanism and the increase of the size of the Georgian block.As a result of these movements, all the main units of the structure of the research territory were formed-faults, fold deformations of a covering type. Since then, the Zemo Imereti Plateau has completely turned into a land, and remains to the Cretaceous period and in some areas before the beginning of the Upper Cretaceous [5] [19]. The folds of the Greater Caucasus and Lesser Caucasus Mountain Systems, which were leaned against the crystalline massif from the north and south, overthrusted the latter.As a result of the Jurassic prophases, the southern slope of the Racha Range (including the Ertso-Tsona areas) turned to be so consolidated that it would hardly respond to mountain forming movements with elastic deformation, and the tension discharge took place mainly in the form of shearings. Since then, the geological development of the southern slope of the Racha Range and Zemo Imereti Plateau is in progress in close relation.

In some parts of the study territory, a transgression of the Kelovian sea takes place.The reef limestones related to the mentioned transgression did not have a wide spread from the very beginning and was mainly stretched along the northern edge of the Georgian block.They were deposited and developed in the Bajoian rock islands, which were slightly jutted out above sea level and formed 60 - 80 meters wide individualstrips [12]. The relics of these strips are the limestone rock-remnants of the Ertso-Tsona hollow, as well as the Valkhokhi, Veluamta and other remnant mountains.Thus, the aforementioned limestone remnant mountains are the remnants of the continuous strip of barrier-type coral reefs formed in the Upper Jurassic.In Kimmeridgian, the sea retreats again. In Lower Neocomian the sea intruded again, but this time it occupied only a part of the Dzirula massif that indicates the existence of quartz cobblestones in all the sections of Cretaceous in the area of Sachkhere [20]. At this time the sea in- 
truded from the north and west. The sea transgression reached the southwestern and southern peripheral part of the massif only in the Upper Hauterivian. The sea regression occurs in Albian under the influence of the Austrian oprogenic phase. In this connection island areas occur.

Thus, after the Bathonian Mountain forming phase, the Dzirula crystalline massif was uplifted and became a land. A new denudation cycle began after the uplifting, due to which the destruction processes in Upper Jurassic and partly in Lower Cretaceous periods (up to Barremian age) flatten the considerable part of the Zemo Imereti Plateau [14]. In addition, it should be noted that the Zemo Imereti Plateau should have been sloped towards the Racha Range (in the north) after the Bathonian orophase and the rivers formed on its surface were flowing to the north in the direction of inclination of this topographic surface [7] [11]. The mentioned fact is confirmed by the topographical map (Figure 3) of the upper tectonic (Mesozoic-Cenozoic) bed of the Chiatura structural plateau compiled by us on the basis of boreholes and geological sections, where it is well seen that the common inclination of the surface of Cretaceous limestones bed is directed from south-west to north-east.

Sedimentary (Jurassic) cover has been completely removed in some areas of the massive as a result of denudation processes after Bathonian orophase, which is proven by the fact that many of the Cretaceous rocks are directly stretched over the crystalline massif. Structural integrity of the Middle Jurassic folds has also been destructed, as there was a significant washing in the Jurassic anticlinal strip. It is obvious that at this time the karstification of carbonate rocks, in particular, the Middle Lias red limestones should have been occurred as well, which is indicated by the sinkholes detected by Kipiani [18] in the limestones of mentioned

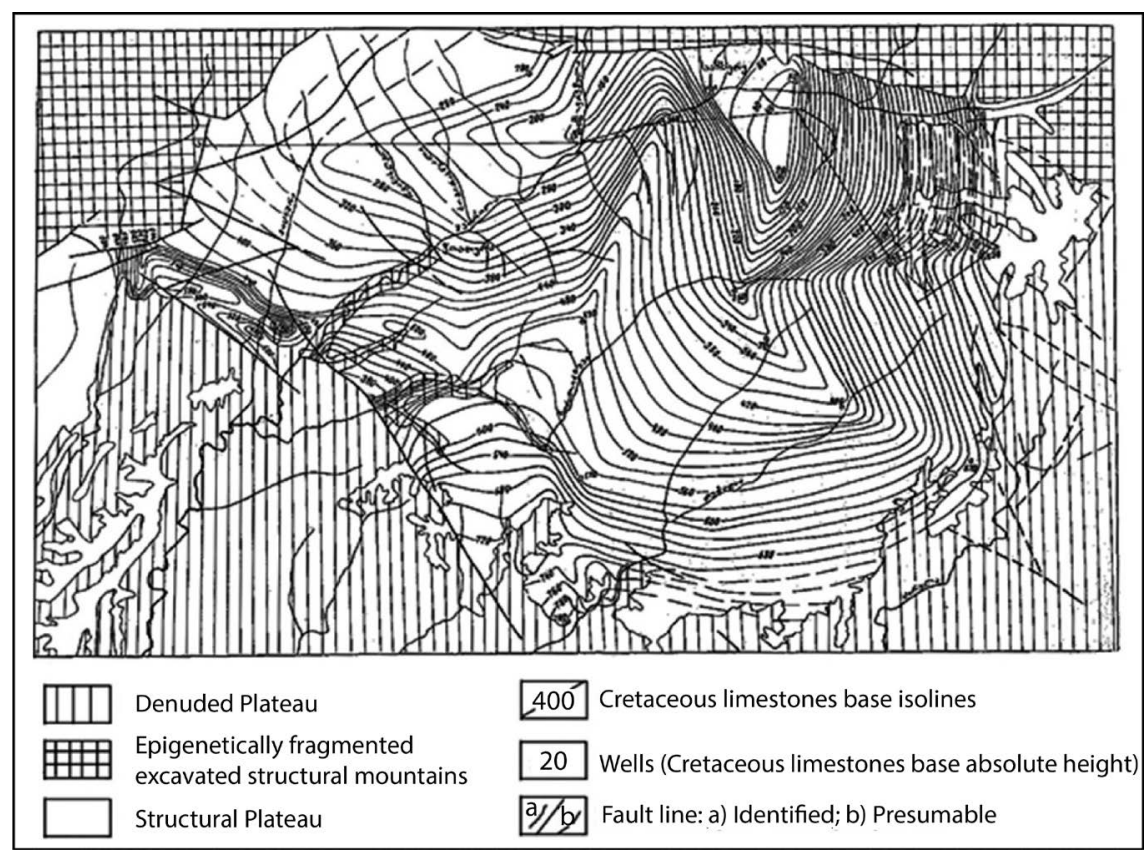

Figure 3. The topography of the bed of upper tectonic level (Meso-Cenozoic) of the Chiatura structural plateau. 
age in the areas of the villages of Katskhi, Salieti, Shrosha and others. During the mentioned period, the intense karstification of Lias limestones is indicated by the unprocessed cobbles and boulders of red limestones included in the Bajocian porphyritic suite in the surroundings of the village of Bzhinevi, as well as the karstified surfaces-corries and sinkholes that are filled with the Upper Cretaceous sediments. Therefore, Kipiani [18] correctly indicates the Jurassic-Cretaceous karst in the Zemo Imereti Plateau, which we suppose, requires additional research.

Two transgressions were observed during Upper Cretaceous: the Senoman sea intruded from the west, indicating the gradual growth of the Senoman transgression from west to east in southern Okriba; in the Lower Turonian, the Senoman transgression was followed by a regression caused by a weak orogenic phase that had been replaced by transgression in the Upper Turonian and extended to the end of the Upper Cretaceous. At this time the limestone is deposited, where the karst phenomena are developed today. In the northern part of Zemo Imereti Plateau, in the vicinities of the villages of Katskhi-Salieti, Rgani, etc., the Upper Cretaceous limestone layers are directly deposited on the Middle Lias color limestones, causing the burying of theJurassic-Cretaceous kart formed in the Middle Lias color limestones, which we have mentioned above.

In Danian, the Dzirula massif was uplifted and turned into a land. Its important part remained as land of the up to Oligocene. In the Eocene, the ascending movements are common in the geosynclinals basin of the southern slope of the Greater Caucasus that have been replaced by the descending movements in the Middle Eocene. The latter caused sea transgression only in the northern peripheral region of Dzirula massif. Adjara-Trialeti geosyncline in the southern part of the region was also sunken in the Middle Eocene. At the end of the Middle Eocene the tectogenesis phase was revealed in both geosynclines and led to the dislocation of sediments deposited in them.In the Upper Eocene, the northern peripheral part of the Dzirula massif and the Adjara-Trialeti geosynclines were sunken and the sea transgression occurred, and the land is still rising and widening at the very end of Upper Eocene.

Therefore, after the deposition of the Upper Cretaceous limestones before deposition of manganese layers in Paleogene, a significant part ofZemo Imereti Plateau is a land and its intense washing takes place. Obviously, during this time, the karstification of the mentioned limestones and the foration of karst forms is underway. And as a result of Middle Oligocene transgression this karstified surface ofUpper Cretaceous limestones is covered firstly with conglomerates or sandstones, and then with the manganese ore layers. The manganese ore layers are stretched directly over the kart surfaces of Upper Cretaceous limestones in some areas (Shukruti, Rgani and Perevisa Plateaus) directly on the surface surfaces of the Upper Cretaceous limestone (Figure 4). Thus, in the study region we have a karst of Lower Tertiary (Palaeocene-Eocene) age.

The Middle Oligocene sea transgression continues in Miocene too and reaches its maximum development in the Lower Sarmatian century. The Samatian sea intruded the Zemo Imereti region from Racha syncline and west from the side of 


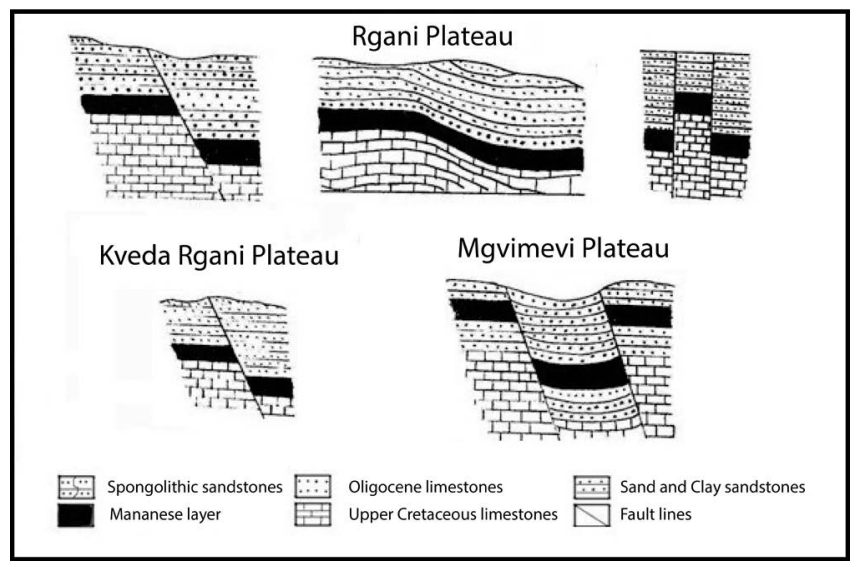

Figure 4. Shearing dislocations and upper cretaceous limestones covered bymanganese ore in the Zemo Imereti Plateau (Gavasheli, 1950).

Chiatura. The coastline nature of sediments confirms that this transgression covered a significant part of the massif. Sedimentary basin of Chiatura occurred. There existed a land in the south-eastern part of the massif together with the aforementioned basin that included modern Likhi and Dzirula-Chkherimela lower strips [5]. The land existed also in the areas of the southern slopes of the Racha Range and Ertso-Tsona. These latter entered the subaerial phase before Miocene, before Styrian orophase [13].

Therefore, in the Upper Miocene simultaneous sedimentation in the Chiatura area (structural plateau) and washing in the surrounding mountains (including the Racha Range Range) took place, which is confirmed by the existence of crystalline rolling materials in the structural plateau sediments.

Post-Miocene tectogenesis was strong in the folded trip of the Greater Caucasus, and the platform massif activity was mainly expressed in vertical (epirogenetic) uplifting, accompanied by small faults and wavy folds of local importance.By the influence of ascending movements the sea finally leaves Zemo Imereti Plateau and adjoining districts and enters the subaerial development stage. Maruashvili [5] considers the Attic or Pre-Kimmeridgian mountain forming phaseas the beginning of thelatter. At the same time, the last manifestation of magmatic activity should have been occurred, which resulted in formation of Goradziri, Perevisa and other lacolith-extrusions. This period is related to the formation of central types of structures (volcanic apparatus, intrusives of isometric forms) we have identified with structural decoding of satellite imagery [3].

Post-Sarmatian folds have changed the peculiarities of the relief of the Zemo Imereti Plateau and the surrounding regions and distribution of hydrographic network. At this time there is a powerful uplifting of the Racha Range, which appeared hipsometrically higher than the Zemo Imereti Plateau. It is obvious that this circumstance has led to the emergence of new directions of hydrographic network approaching modern conditions. On the southern slopes of the Racha Range, the rivers were dislocated meridionally with the inclination of the primary topography. At the same time they looked latitudinal byselective erosion. 
On the structural plateau of Chiatura itself, the direction of the rivers does not coincide with the original sloping of the surface.After the final liberation from the sea, the sloping of the above-mentioned Plateau surface was of south-western direction. The rivers also flowed in this directionWhen they developed pretty deep gorges, there was a tomb-like raising that led to the sloping of the Chiatura structural plate to the north-west [5]. This raising, apparently, has not substantially altered the existing hydro network alignment and has continued to flow in their previously generated channels.

In the formation of canyon gorges and definition of the direction of rivers the tectonic fissures have played an important role in 1928, noted V. Bogachov. The fault dislocation schemeof the Chuatura structural plateau [21] made based on the decoding satellite imagery, gives the imagination about above mentioned. In determining the direction of rivers, thesignificantrolehas also played the character of the primary topographic surfaceof the structural plateau in close relation with selective erosion.

Hence the hydronetwork conception began with in the structural plateau at the end of the Sarmatian century, and in the Racha and Likhi Range lines -much earlier.In this regard, for the Zemo Imereti Plateau, as L. Maruashvili [5] notes, the modern geomorphological cycle began at the edge of the Lower Pliocene and Middle Pliocene (formation of erosion, karst and other forms took place during the Middle Pliocene, Upper Pliocene and Quaternary) and in the south-east of the massif, in the areas of crystalline rocksoutcrop and in the strip of the southern slope of the Racha Range-in Lower Pliocene or earlier. This distinction is clearly reflected on modern relief. For example, as the result of strong and long denudation almost no young sediments have been remainedin the southern slope of the Racha Range; in the area of the Ertso Lake the remnant limestone relief has been developed, and in the south-eastern part of the massif and in the strip of the Likhi Range, itself Dzirula crystalline massif is outcropped as it was mentioned above (Figure 2).

The initial phase of the modern geomorphologic cycle was expressed by the weak erosion of hydro network within the structural plateau. Plain relief gets a weakly hilly form. At this time the plateau seemed to have low hypsometric stages and represented the accumulation district of alluvial sediments brought from the surrounding orographic units (Dzirula-Chkherimela and Likhi Ranges, Greater Caucasus and Lesser Caucasus). These paleomorphological conditions are confirmed by the well-rolled round stones of crystalline rocks detected in the wavy and plain watersheds [5]. This is confirmed by well-processed round stones detected by us in the sediment section at the entrance of the Rganisklde Cave, which are brought from the Racha Range.

In the mentioned period, within the structural plateau, rivers still cannot reach limestones and karst process does not take place. The depth of the erosive intersection here does not exceed several dozen meters.At this time, in the areas of old peneplain, the depth of erosive fragmentation varies between $400-600$ meters (modern fragmentation is 700 - 900 meters).In the area of the Racha 
Range, namely, in the vicinities of Khreiti, Satsalike and Ertso-Tsona, which was freed of the sea earlier, the significant deepening of hydro network was accompanied by the vigorous course of karst processes. That is why the karst of the limestone strip of the Racha Range is significantly older than that of Zemo Imereti. This is confirmed by the results of lithological research of the terrigenous sediments conducted by us in the karst caves of Zemo Imereti Plateau [3] [4] [21] [22] [23]. In the Zemo Imereti Plateau, after the gorge was cut into limestone suite, and the Tertiary rocks on it were washed or became thinner, favorable conditions were created for karsting. In this regard, the second phase of modern geomorphologic cycle was found to be highly fruitful for the Zemo Imereti structural plateau that was associated with Upper Pliocene orogenetic phase and that caused the uplifting of the plateau and associated with it intense depth erosion.

Intensified deepening of rivers was accompanied by intensive action of underground waters and processing of karst cavities. The hydrographic network has reached the Upper Cretaceous lime stones (which was partially karstified still in the Tertiary period), started to leak into it. Therefore, some of the river dried out and the gorged ceased erosive development. At the same time, the Kvirila River and its main tributaries continued intense depth erosion and resulted in forming deep canyon shaped gorges. These dead gorges (former river valleys) are at present distributed at different altitudes from the foot of Kvirila and its main tributaries. The consequences of actions of such former hydrographic network are found many in the Salieti-Sachkhere section on both sides of the Kvirila River. Along the channels of former hydrographic network (hanging valleys), the intensive karstification took place and the sinkholes were formed, which are characteristic of the Zemo Imereti Plateau. Simultaneously with the erosion of the rivers the washing of the limestone-protective surface rocks (the Oligocene-Miocene sandy-clay deposits) less resistant to the denudation agents. The reduction of the thickness of the layers stretched over the limestones and their good water permeability led to the wider development of sinking karst sinkholes, which transmit surface waters into the depths.

The intense ascending tectonic movements and pause epochs of a short duration mainly stipulated the storey layout of the caves in the Zemo Imereti Plateau, as well as the wide distribution of the tunnel (or hole) types of underdeveloped caves, and weakly observed terraced levels. The enhanced and at the same time the permanent erosion of the Kvirila River and its tributaries created favorable conditions for groundwater circulation. In the generated caverns the underground streams of reduced mass began to flow. Many of the caves remained waterless after shifting hydro network into the depth, and in some areas, where the considerable mass of water shifted into the depth along the fissure, the underground waters formed the caves in the lower levels. In some cases, they reached even the main river level. As it is proven by the indicator tests conducted by us, the different conditions for the development of caves in the study area have determined the formation of independent flows of water, the main basis of which is 
the Kvirila River. Additionally, at modern stage the individual karst caves, shafts, wells and channel of vaucluse sources formed at early stages, were united in a single karst water content system that is still impassable for humans, and within which the development of karst cavities continues [3] [21].

At the last stage of the modern geomorphological cycle (in Holocene), temporary flows are important factors that actively participate in the creation and expansion of underground cavities. Today, as a result ofhuman activitythe soil-vegetation cover of the study territory is completely or partly destroyed, and within the Chiatura structural plateau, there is also the destruction of the sheet surface, the formation of fractures (as a result of explosions in quarries and quarries) and etc. All this enhances the rapid leakage of atmospheric precipitations into the limestone and the activation of karst, and occasionally causing the strongest turbulence-pollution.

\section{Conclusions}

The borders of the karst region of the Zemo Imereti Plateau coincide with the surface contact line of the Cretaceous limestones, which is a geological substrate of the karst and is represented by older formations (Bajocianporphyritic suite in the north and east, and Middle Paleozoic granitoids in the south and west). The Cretaceous limestones foundation created Paleozoic formations, which underwent denudation and peneplaining of the most part in the Upper Jurassic and partly in the Lower Cretaceous periods after the Bathonian orogenesis phase. In addition, it should be noted that the Zemo Imereti Plateau was angled towards the Racha Range (in the north) after the Bathonian orophase, and that the rivers formed on its surface flew to the north, to the direction of topographic surface inclination. This fact is confirmed by the topographical map of the upper tectonic (mesozoic-kinosous) bed of the Chiatura structural plateau mapped by us on the basis of wells and geological sections (Figure 3).

The existence of a peneplain solid Hercynian platform stipulated the character of the layout (smooth horizontal or slightly angled layout) of Meso-Cenozoic cover lying on it, which was represented mainly by Valanginian-Hauterivian, Barremian and Turonian-Danianlimestones, Tertiary clays and sandstones. The sedimentation of these sediments were underway in the platform conditions, and in connection with this, their overall capacity did not exceed 500 - 550 meters.

On the basis of field surveys within the study area in the Zemo Imereti Plateau, karst and karst forms of the Jurassic-Cretaceous, Lower Tertiary (Paleocene-Eocene) and Post-Miocene (Sarmati) period were revealed. Post Miocene technogenesis was strong in the folded strip of the Caucasus, and the activity of the block massif was expressed mainly in the vertical (epigenetic) uplifting. As identified by researches, the modern geomorphological cycle began at the edge of Lower Pliocene and Middle Pliocene for the Zemo Imereti Plateau. The origination and development of erosive, karst and other forms took place in the mentioned area during the Middle Pliocene, Upper Pliocene and Quaternary. 
The intensive ascending tectonic movements developed in the Post-Sarmatian century and the epochs of a short delay stipulated mainly thestorey layout of the caves presented here and the wide distribution of tunnel-type caves.

Archaeologically dated cultural deposits in the caves of the study area and the lithobiostratigraphical analysis of the cave subterranean sediments conducted by us enabled us to identify the cave age. In Zemo Imereti Plateau, in the caves located today on higher hypsometric levels, the sedimentation of subterranean sediments began in the Middle-Upper Pleistocene and it seemed that the mentioned caves formation was mainly completed. On the southern slope of the Racha Range and in the area of Ertso-Tsona, the age of archaeologically dated sediments was Lower Pleistocene and it seemed that the formation of the caves was already completed before Pleistocene.

There are many limestone massifs in Georgia that differ from each other with morphological peculiarities, structural-tectonic structures, hydrogeological conditions, hypsometric distribution, etc. Therefore, the group of authors plans to conduct similar fundamental researches in other limestone massifs of Georgia, which is very important.

\section{Acknowledgements}

We thank Giorgi Gaprindashvili (Doctor of Geography, TSU) for assistance in the preparation of this paper.

\section{Conflicts of Interest}

The authors declare no conflicts of interest regarding the publication of this paper.

\section{References}

[1] Gamkrelidze, P.D. (1969) The Structure and Development of the Western Part of the Southern Slope of the Greater Caucasus and the Georgian Block. "Geotectonica", No. 4, Tbilisi. (In Russian)

[2] Gamkrelidze, P.D. (1975) Scheme of Tectonic Division of the Territory of Georgia. In: Guidebook of the Soviet-Indian Symposium on the Comparative Geology of the Caucasus and the Himalayas, Tbilisi. (In Russian)

[3] Lezhava, Z. (2015) The Karst of Zemo Imereti Plateau and Its Surrounding Areas. Universali, Tbilisi. (In Georgian)

[4] Asanidze, L., Chikhradze, N., Lezhava, Z., Tsikarishvili, K., Polk, J. and Chartolani, G. (2017) Sedimentological Study of Caves in the ZemoImereti Plateau, Georgia, Caucasus Region. Open Journal of Geology, 7, 465-477.

[5] Modern Relief and Geomorphological History of the Zemo Imeretsko Plateau. Proceedings of the Vakhushti Bagrationi Institute of Geography of the ASGSSR. (In Russian)

[6] Bogachev, V.V. (1929) Geological Outline of Chiatura Basin. Proceedings of the Azerbaijan State Polytechnic Institute, Tbilisi, 1929, Vol. 6.

[7] Markov, K.V. (1931) Chiatura Manganese Region. Proceedings of the geol. explor. admin. of SSNE USSR, No. 27, M-L. (In Russian)

[8] Gamkrelidze, P.D. (1933) The Geological Structure of the Part of the Dzirula and 
Chkherimela River Gorges. Bulletin of the Institute of Geology of Georgia, 1. (In Russian)

[9] Kuznetsov, I.G. (1937) Geological Structure of the Part of Western Georgia within Racha, Lechkhumi and Imereti. International Geological Congress, XVII Session, USSR, Excursion to the Caucasus, Georgian SSR, Western Part, L-M. (In Russian)

[10] Janelidze, A.M. (1940) Geological Observations in Okriba and in the Adjacent Parts of Racha and Lechkhumi. Tbilisi. (In Russian)

[11] Janelidze, A.M. (1940) The Problem of Georgian Block. Bulletin of the ASGSSR, 3. (In Georgian)

[12] Kakhadze, I.R. (1941) To the Stratigraphy of the Upper Cretaceous of the Northern Periphery of the Dzirulamassif. Bulletin of the ASGSSR, 2. (In Russian)

[13] Kakhadze, I.R. (1948) Georgia in the Jurassic Period. Works of the Inst. Geol. ASGSSR, 3. (In Russian)

[14] Chikhelidze, S. (1948) Geological Observations in the South-Eastern Part of the Dzirula Massif. Works of the Inst. Geol. Acad. of Sc. of Georgia, 4. (In Georgian)

[15] Shiriashvili, O.I. and Vashakidze, I.G. (1972) Geological Description of the Sheets: K-38-52-VG; K-38-64-A, B (the Kvirila, Dzirula, Grone and Liakhvi River Basins). Report of Liakhvi “GSP” by Works of 1966-1970. Funds of the "Gruzgeolupravleniya”, Tb. (In Russian)

[16] Geguchadze, Sh. (1973) Geology and Development History of the Rioni-Kvirila Watershed. Tbilisi. (In Georgian)

[17] Kuchukhidze, G.T., et al. (1986) Report on the Hydrogeological Survey of the Scale: 1: 50000 of the Zemo Mereti Plateau by Works of 1983-1986. Funds of the "Gruzgeoloupravleniya”. (In Russian)

[18] Gudjabidze, G.E. (2003) Geological Map of Georgia, Scale 1:500 000. In: Gamkrelidze, et al., Eds., Georgian State Department of Geology and National Oil Company "Saqnavtobi", Tbilisi.

[19] Kipiani, Sh. (1959) Geomorphological Peculiarities of the Karst Regions of the Zemo Imereti Massif. The Works of the Geographical Society of the Georgian SSR, Vol. 4, Tbilisi. (In Georgian)

[20] Eristavi, M.S. (1948) Georgian Block and Adjacent Areas in Lower Cretaceous Period. Institute of Geology and Mineralogy, ASGSSR, Tb. (In Russian)

[21] Lezhava, Z., Bolashvili, N., Tsikarishvili, K., Asanidze, L. and Chikhradze, N. (2015) Hydrological and Hydrogeological Characteristics of the Platform Karst (Zemo Imereti Plateau, Georgia). 14th Multidisciplinary Conference on Sinkholes and the Engineering and Environmental Impacts of Karst, Rochester, 2015, 93-100.

[22] Asanidze, L., Chikhradze, N., Lezhava, Z., Tsikarishvili, K., Polk, S.J., Lominadze, G. and Bolashvili, N. (2017) Complex Speleogenetic Processes and Mineral Deposition in the Caucasus Region of Georgia. Journal of Environmental Biology, 38, 1107-1113.

[23] Asanidze, L., Lezhava, Z., Tsikarishvili, K., Chikhradze, N. and Polk, J. (2017) Karst Morphological Processes and Evolution of the Limestone Massif of Georgia from Depositional, Sedimentary, and Structural Investigations in Muradi Cave. Proceedings of 17 th International Congress of Speleology, Sydney, 2017, 241-247. 